\title{
Nitrogen Fertigation in Lettuce Culture
}

\author{
Giovane Munhoz Pedrilho \\ Graduate in Agronomy at the University Center of Maringá - UNICESUMAR, 1610 Guedner \\ Ave Maringá, Paraná, Brazil \\ E-mail: giovanemunhoz2008@hotmail.com
}

João Vitor da Silva Fernandes

Graduate in Agronomy at the University Center of Maringá - UNICESUMAR, 1610 Guedner Ave Maringá, Paraná, Brazil

E-mail: joaoovitorfernandes@gmail.com

André Ribeiro da Costa (Corresponding author)

$\mathrm{PhD}$, Professor of the Master's Program in Science, Technology and Food Safety at the University Center of Maringá - UNICESUMAR, Maringá-Paraná. Researcher and Fellow Research Productivity of ICETI - Cesumar Institute of Science, Technology and Innovation, 1610 Guedner Ave Maringá, Paraná, Brazil

E-mail: andre.costa@unicesumar.edu.br

Anny Rose Mannigel

$\mathrm{PhD}$, Professor of the Master's Program in Science, Technology and Food Safety at the University Center of Maringá - UNICESUMAR, Maringá-Paraná. Researcher and Fellow Research Productivity of ICETI - Cesumar Institute of Science, Technology and Innovation, 1610 Guedner Ave Maringá, Paraná, Brazil

E-mail: anny.mannigel@unicesumar.edu.br

\section{Daniele Fernanda Felipe}

$\mathrm{PhD}$, Professor of the Master's Program in Science, Technology and Food Safety at the University Center of Maringá - UNICESUMAR, Maringá-Paraná. Researcher and Fellow Research Productivity of ICETI - Cesumar Institute of Science, Technology and Innovation, 1610 Guedner Ave Maringá, Paraná, Brazil

E-mail: daniele.felipe@ unicesumar.edu.br 


\section{Graciene de Souza Bido}

$\mathrm{PhD}$, Professor of the Master's Program in Science, Technology and Food Safety at the University Center of Maringá - UNICESUMAR, Maringá-Paraná. Researcher and Fellow Research Productivity of ICETI - Cesumar Institute of Science, Technology and Innovation, 1610 Guedner Ave Maringá, Paraná, Brazil

E-mail: graciene.bido@ unicesumar.edu.br

\section{Ricardo Andreola}

$\mathrm{PhD}$, Professor of the Master's Program in Science, Technology and Food Safety at the University Center of Maringá - UNICESUMAR, Maringá-Paraná. Researcher and Fellow Research Productivity of ICETI - Cesumar Institute of Science, Technology and Innovation, 1610 Guedner Ave Maringá, Paraná, Brazil

E-mail: ricardo.andreola@ unicesumar.edu.br

\section{Roberto Rezende}

Professor of the Postgraduate Program in Agronomy of the State University of Maringá, State of Paraná, 5790 Colombo Ave Maringá, Paraná, Brazil

E-mail: rrezende@uem.br

\section{Paulo Sérgio Lourenço de Freitas}

Professor of the Postgraduate Program in Agronomy of the State University of Maringá, State of Paraná, 5790 Colombo Ave Maringá, Paraná, Brazil

E-mail: pslfreitas@uem.br

\section{Antônio Carlos Andrade Gonçalves}

Professor of the Postgraduate Program in Agronomy of the State University of Maringá, State of Paraná, 5790 Colombo Ave Maringá, Paraná, Brazil

E-mail: acagoncalves@uem.br

Received: Sep. 16, 2019

doi:10.5296/jas.v8i1.15450
Accepted: Oct. 23, 2019 Published: Oct. 24, 2019

URL: https://doi.org/10.5296/jas.v8i1.15450 


\section{Abstract}

Lettuce (Lactuca sativa L.) is the most consumed vegetable in the world and in Brazil, representing as an important dietary source of vitamins, fiber and minerals to population. The aim of this study was to evaluate the yield of lettuce against nitrogen doses applied via fertigation, as well as the quality of the administered fertilizer solution. The test was carried out in an agricultural area located in the Doutor Camargo municipality, Northwestern of Paraná State, Brazil. The experiment was designed in a completely randomized design with seven treatments: T1 control - $0 \mathrm{~kg} \mathrm{ha}^{-1}$ urea $\left(0 \mathrm{~kg} \mathrm{~N}^{-1}\right)$; $\mathrm{T} 2-25 \mathrm{~kg} \mathrm{ha}^{-1}$ urea $\left(11.25 \mathrm{~kg} \mathrm{~N}^{-1}\right)$; T3 $50 \mathrm{~kg} \mathrm{ha}^{-1}$ urea $\left(22.5 \mathrm{~kg} \mathrm{~N} \mathrm{ha}^{-1}\right)$; $\mathrm{T} 4-75 \mathrm{~kg} \mathrm{ha}^{-1}$ urea $\left(33.75 \mathrm{~kg} \mathrm{~N} \mathrm{ha}^{-1}\right)$; T5 - application of 100 $\mathrm{kg} \mathrm{ha}^{-1}$ urea (45 $\left.\mathrm{kg} \mathrm{N} \mathrm{ha}^{-1}\right)$; $\mathrm{T} 6$ - $125 \mathrm{~kg} \mathrm{ha}^{-1}$ urea $\left(56.25 \mathrm{~kg} \mathrm{~N} \mathrm{ha}^{-1}\right)$; $\mathrm{T} 7-150 \mathrm{~kg} \mathrm{ha}^{-1}$ urea $(67.5$ $\mathrm{kg} \mathrm{N} \mathrm{ha}{ }^{-1}$ ). Each treatment had six repetitions. Seeds from Dora (American lettuce) and Vera (curly lettuce) varieties were used for seedling production. Nutrients were applied to the crop by fertigation at 15 and 30 days after transplanting the seedlings to the seedbeds. Fresh shoot mass (weight), stem diameter, root length and productivity were assessed. Results showed that nitrogen fertilization via fertigation significantly influenced the growth and yield variables of plants from both Dora and Vera varieties.

Keywords: efficiency, food, yield

\section{Introduction}

Lettuce (Lactuca sativa, family Asteraceae) is an herbaceous plant from Asia which possess tender consistency and a small stem (Targino et al., 2017). Its leaves, which can be smooth or curly, grow in rosette shape around the stem, forming or not a "head", and can present various shades of green or purple according to the cultivar. It is the most consumed vegetable in the world and in Brazil, being used in salads and sandwiches, especially in self-service restaurants, thus figuring as an important dietary source of vitamins, fiber and minerals (Filgueira, 2013).

Lettuce crop occupies an area of 35,000 hectares in intensive family production, which generates about five jobs per cultivated hectare (Sousa et al., 2016). Due to its short cycle, lettuce culture is nutrient demanding and requires the use of organic fertilizers to meet plant nutritional demands.

As the crop is basically composed of leaves, it responds well to the supply of nitrogen. However, this nutrient requires special fertilization management; first, because it is easily leached, and second because lettuce absorbs it more in the final phase of the cycle. Nitrogen deficiency slows plant growth (Almeida et al., 2011), induces head malformation and yellowing of older leaves (Goto et al., 2001).

Nitrogen $(\mathrm{N})$ is an essential element and is usually the nutrient most required by crops. For lettuce, $\mathrm{N}$ is the second most extracted chemical element (Benini et al., 2005). In general, the recommended nitrogen fertilization for lettuce is about 100 to $130 \mathrm{~kg} \mathrm{ha}^{-1}$ of $\mathrm{N}$ or 40 to $60 \mathrm{t}$ $\mathrm{ha}^{-1}$ of corral manure (IAC, 2005).

Crop productivity is directly related to several aspects including plant health, soil moisture 
and available nutrient levels (via soil fertility or fertilizer application) (Carrijo et al., 2004). With the development of irrigation systems, fertilization of lettuce crops via fertigation became a strategy to increase productivity and reduce production costs.

With the reduction of water supply for various purposes, which include the practice of irrigation and direct human consumption, the study of more rational techniques of water use has been increasingly constant fact (Alves et al., 2018). Thus, the use of fertigation can contribute to a better use of water in agricultural operations, since the fertilizer to be applied to the plant can be supplied by irrigation water, which contributes to the reduction of production costs of a crop. Besides that, balance between quantity of nutrients and applied water is necessary, to maintain appropriate concentration of fertilizers in the irrigation water, for an appropriate crop development, providing nutrient absorption in required quantities (Zamora et al., 2019).

Nitrogen $(\mathrm{N})$ is the most abundant nutrient, constituent of amino acids, proteins, nitrogenous bases, chlorophyll, hormones and among other molecules, being absorbed in larger quantities by the plant (Silva et al., 2014). Their lack in the seedling formation phase reflects the decrease in growth and development, and affects the final crop yield (Zhang et al., 2012) due to the reduction of total biomass accumulation.

Kappes, Zancanaro and Jesus (2013) explain that the dynamics of $\mathrm{N}$ in the soil-plant system is mainly influenced by cultivation systems, management, edaphoclimatic conditions and type of fertilizer, with urea being the most used nitrogen source in the soil, due to its concentration $(45 \% \mathrm{~N})$ and, accordingly, lower cost. However, nowadays there are different sources of nitrogen available on the market, each with its own peculiarities and advantages, which are employed within the most appropriate management in relation to the agricultural production cycle, in order to maximize production, minimize costs and provide greater profitability for producers (Lopes, 2012).

$\mathrm{N}$ is found in organic compounds such as amino acids and nucleic acids. It participates in several vital physiological processes for the plant life cycle - ionic absorption, photosynthesis, respiration, cell multiplication and differentiation, and inheritance. This nutrient, when absorbed by the roots, is transported via the transpiratory current to the plant parts through the xylem vessels and is easily redistributed via phloem as amino acids. Thus, in the absence of $\mathrm{N}$, this nutrient is mobilized from old leaves to newer organs and leaves. Consequently, in deficient plants, symptoms first appear in old leaves (Taiz, et al., 2017).

In Brazil, many agricultural areas are irrigated with water contaminated by pesticides and fecal material. Thus, raw vegetables are vehicles for the transmission of human pathogens (Takayanagui et al., 2000). Contamination can occur as a result of irrigation water or inadequate fertilizers, harvesting, transportation, and retail handling. Successive manipulations increase the chances of contamination.

Bearing the importance of $\mathrm{N}$ for lettuce culture in mind, the present work aimed to evaluate lettuce productivity as a function of different nitrogen sources and doses applied via fertigation. 


\section{Material and Methods}

The experiment was conducted in the first semester of 2018 in an open field with total area of $144 \mathrm{~m}^{2}$, at Monvic Ranch, located in Marist Road, Doctor Camargo municipality, Northwestern Paraná State, Brazil, with latitude $23^{\circ} 35^{\prime} 44.11$ "S, longitude $52^{\circ} 16 ' 58.74$ " W and elevation of 287 meters.

The soil of the experimental area was classified as Eutrophic Red Latosol (EMBRAPA, 2018), of clay texture, under regional conditions of subtropical climate, that is, of the Cfa type according to Köppen classification, with abundant and well distributed rainfall throughout the year and cool and humid summer (Sala \& Costa, 2012).

Soil preparation was performed with a rotary hoe coupled to a tractor. Subsequently, completion of the seedbeds was carried out employing manual hoes. Each plot corresponded to a $48 \mathrm{~m}^{2}$ plot $(1.2 \mathrm{~m}$ wide $\mathrm{x} 40 \mathrm{~m}$ long), resulting in 240 plants per plot. Thus, the plot encompassed 3 rows of plants, and the usable area consisting of a central row was formed by 80 plants.

Lettuce seedlings were made using Dora (American lettuce) and Vera (curly lettuce) varieties seeds, in expanded polystyrene trays with capacity for 100 cells. Coconut fiber substrate (Golden Mix Granulated) composed of $100 \%$ fine texture coconut fiber without base fertilization were used. Seedlings were transplanted to the experimental area after 21 days in tray cultivation, considering as ideal seedlings for transplant operation those that presented three to four definitive leaves (Filgueira, 2013).

The experiment was designed in a completely randomized design with seven treatments and six replications. Urea, which has $45 \%$ of nitrogen, was used as nitrogen source (Novais et al., 2007). Varying doses of nitrogen fertilizer were tested, as follows: $\mathrm{T} 1 \mathrm{control}-0 \mathrm{~kg} \mathrm{ha}^{-1}$ urea (0 kg N ha $\left.{ }^{-1}\right)$; $\mathrm{T} 2$ - $25 \mathrm{~kg} \mathrm{ha}^{-1}$ urea $\left(11.25 \mathrm{~kg} \mathrm{~N} \mathrm{ha}^{-1}\right)$; $\mathrm{T} 3-50 \mathrm{~kg} \mathrm{ha}^{-1}$ urea $\left(22.5 \mathrm{~kg} \mathrm{~N} \mathrm{ha}^{-1}\right)$; T4 - $75 \mathrm{~kg} \mathrm{ha}^{-1}$ urea $\left(33.75 \mathrm{~kg} \mathrm{~N} \mathrm{ha}^{-1}\right)$; T5 - application of $100 \mathrm{~kg} \mathrm{ha}^{-1}$ urea $\left(45 \mathrm{~kg} \mathrm{~N} \mathrm{ha}^{-1}\right)$; $\mathrm{T} 6$ $125 \mathrm{~kg} \mathrm{ha}^{-1}$ urea $\left(56.25 \mathrm{~kg} \mathrm{~N} \mathrm{ha}^{-1}\right)$; $\mathrm{T} 7-150 \mathrm{~kg} \mathrm{ha}^{-1}$ urea $\left(67.5 \mathrm{~kg} \mathrm{~N} \mathrm{ha}^{-1}\right)$.

Irrigation started shortly after transplantation on a daily basis, with the drip system running at 180 liters of water per day. The system consisted of dripping tapes, distributed in three per plot and installed at the soil surface between the plant lines; drippers were spaced every 0.40 $\mathrm{m}$. Water applications were performed when tensiometers recorded tensions of $20 \mathrm{KPa}$, being this critical value previously established by Marouelli (2008).

Irrigation management was performed based on the estimated maximum crop evapotranspiration (ETm), according to the method proposed by FAO 56 (ALLEN et al., 2006), applying the double crop coefficient value (Kc) methodology. FAO 56 recommends $\mathrm{Kcb}$ (basal culture Kc) values of $0.70,1.00$ and 0.95 for lettuce in the initial, intermediate and late stages of the crop cycle, respectively.

At the end of the crop cycle, the soil was well moistened to facilitate removal of the entire plant, which was sectioned at the height of the neck. In a sample of 6 plants, the roots and shoots were washed and the following response variables were evaluated: 
- Fresh shoot mass (FSM): determined by the weighing of lettuce aerial parts by digital scale;

- Stem diameter (SD): determined through the use of a digital caliper, this was placed on the stem of the evaluated plants;

- Root length (RL): determined using a $30 \mathrm{~cm}$ ruler;

- Productivity: determined by the relationship between the fresh mass of the shoot and the area occupied by the plants of each treatment $\left(\mathrm{t} . \mathrm{ha}^{-1}\right)$.

Data was obtained using the Levene and Shapiro - Wilk tests to evaluate the variance homoscedasticity and the error normality, respectively. Variance analysis was performed and when significant differences in nitrogen doses were observed, the Scott-Knott Test of Medias was applied. SISVAR® statistical software was used. All statistical tests had a significance level of $5 \%$.

\section{Results and Discussions}

As shown in Table 1, the nitrogen rates applied via fertigation significantly affected the fresh air mass, root length, stem diameter and productivity of lettuce plants of Dora variety.

Table 1. Performance of growth variables fresh shoot mass (FSM), stem diameter (SD), root length (RL), and yield variable (productivity) of Dora variety (American lettuce)

\begin{tabular}{ccccc}
\hline Treatments & $\begin{array}{c}\text { FSM } \\
(\text { grams })\end{array}$ & SD (cm) & RL $(\mathrm{cm})$ & Productivity $\left(\mathrm{t} \mathrm{ha}^{-1}\right)$ \\
\hline $\mathrm{T} 1-\left(0 \mathrm{~kg} \mathrm{of} \mathrm{N} \mathrm{ha}{ }^{-1}\right)$ & $550.33 \mathrm{a}$ & $2.04 \mathrm{c}$ & $13.08 \mathrm{c}$ & $54.46 \mathrm{~b}$ \\
$\mathrm{~T} 2-\left(11.25 \mathrm{~kg} \mathrm{of} \mathrm{N} \mathrm{ha}^{-1}\right)$ & $427.00 \mathrm{~b}$ & $3.04 \mathrm{~b}$ & $18.22 \mathrm{a}$ & $47.41 \mathrm{~b}$ \\
$\mathrm{~T} 3-\left(22.5 \mathrm{~kg} \mathrm{of} \mathrm{N} \mathrm{ha}^{-1}\right)$ & $602.33 \mathrm{a}$ & $3.65 \mathrm{a}$ & $19.33 \mathrm{a}$ & $66.88 \mathrm{a}$ \\
$\mathrm{T} 4-\left(33.75 \mathrm{~kg} \mathrm{of} \mathrm{N} \mathrm{ha}^{-1}\right)$ & $525.00 \mathrm{a}$ & $2.48 \mathrm{c}$ & $13.00 \mathrm{c}$ & $58.26 \mathrm{a}$ \\
$\mathrm{T} 5-\left(45 \mathrm{~kg} \mathrm{of} \mathrm{N} \mathrm{ha}^{-1}\right)$ & $561.83 \mathrm{a}$ & $2.16 \mathrm{c}$ & $15.35 \mathrm{~b}$ & $62.38 \mathrm{a}$ \\
$\mathrm{T} 6-\left(56.25 \mathrm{~kg} \mathrm{of} \mathrm{N} \mathrm{ha}^{-1}\right)$ & $569.67 \mathrm{a}$ & $2.27 \mathrm{c}$ & $15.50 \mathrm{~b}$ & $63.25 \mathrm{a}$ \\
$\mathrm{T} 7-\left(67.5 \mathrm{~kg} \mathrm{of} \mathrm{N} \mathrm{ha}^{-1}\right)$ & $549.00 \mathrm{a}$ & $1.97 \mathrm{c}$ & $16.07 \mathrm{~b}$ & $60.95 \mathrm{a}$ \\
\hline $\mathrm{CV} \%$ & 16.71 & 13.84 & 10.87 & 16.12 \\
\hline
\end{tabular}

Averages followed by different letters in the lines differ significantly from each other by Scott-Knott test at 5\% probability level.

All treatments significantly influenced the fresh mass values of Dora shoots; however, the 


\section{Ml Macrothink}

best performances were obtained for treatments T1, T3, T4, T5, T6 and T7, which were all superior to $\mathrm{T} 2$.

Regarding stem diameter, the best result was achieved by the application of T3 treatment, i.e., $22.5 \mathrm{~kg} \mathrm{~N} \mathrm{ha}^{-1}$. T3 differed statistically from T2 (11.25 $\left.\mathrm{kg} \mathrm{N} \mathrm{ha}^{-1}\right)$. Notwithstanding, the other treatments applied to the lettuce plant did not differ from each other. They similarly influenced the fresh air mass of the lettuce plants whereas presented worse performance of the cited variable compared to treatments $\mathrm{T} 3$ and $\mathrm{T} 2$, respectively.

Root length was significantly influenced by the nitrogen doses provided. T2 and T3 treatments produced the best effects on the lettuce roots and differed from the other treatments. It is noteworthy that when comparing the performance of treatments T5, T6 and $\mathrm{T} 7$, they did not differ from each other, being statistically superior to treatments $\mathrm{T} 1$ and $\mathrm{T} 4$ and at the same time being statistically inferior to treatments T2 and T3.

In relation to productivity, the applications of urea performed in T3, T4, T5, T6 and T7 treatments brought the most relevant increments. However, the effects on lettuce yield did not differ from each other and were statistically superior to the effects observed in T1 and T2 treatments.

The results herein reported corroborate data from other authors. Mota et al. (2016), for instance, when evaluating the effect of nitrogen doses provided by various products (among which urea) on lettuce crop growth variables verified that stem diameter and fresh shoot mass were significantly affected, and that the dose of $61 \mathrm{~kg} \mathrm{ha}^{-1} \mathrm{~N}$ rate provided the best fresh mass outcomes.

Concerning stem length, our results were superior to those reported by Brzezinski et al. (2017). The authors found an average value of $2.54 \mathrm{~cm}$ for stem diameter when studying the production of lettuce from Angelina, Rubette, Great Lakes 659 and Tainá varieties in open field.

Both shoot fresh mass and productivity performance may have been indirectly influenced by plant leaf number. The number of leaves is a characteristic in lettuce, not only because they are the commercialized part of the vegetable (Filgueira, 2013), but also because the consumer makes the purchase per unit and not by weight, observing the appearance, volume and number of leaves per head (Diamante et al., 2013). Thus, the greater amount of leaves per plant usually results in greater leaf area, greater fresh mass and, consequently, productivity (Araujo Neto et al., 2009).

Table 2 displays the results obtained in the monitoring of Vera variety for the studied response variables. 
Table 2. Performance of growth variables fresh shoot mass (FSM), stem diameter (SD), and root length (RL), and yield variable (productivity) of Vera variety (curly lettuce)

\begin{tabular}{|c|c|c|c|c|}
\hline Treatments & $\begin{array}{c}\text { FSM } \\
\text { (grams) }\end{array}$ & $\mathrm{SD}(\mathrm{cm})$ & $\mathrm{RL}(\mathrm{cm})$ & Productivity $\left(\mathrm{t} \mathrm{ha}^{-1}\right)$ \\
\hline $\mathrm{T} 1-\left(0 \mathrm{~kg}\right.$ of $\left.\mathrm{N} \mathrm{ha}^{-1}\right)$ & $346.67 \mathrm{~b}$ & $2.31 \mathrm{~b}$ & $16.50 \mathrm{~d}$ & $38.48 \mathrm{~b}$ \\
\hline $\mathrm{T} 2-\left(11.25 \mathrm{~kg}\right.$ of $\left.\mathrm{N} \mathrm{ha}^{-1}\right)$ & $558.67 \mathrm{a}$ & $3.00 \mathrm{a}$ & $24.75 \mathrm{a}$ & $62.05 \mathrm{a}$ \\
\hline $\mathrm{T} 3-\left(22.5 \mathrm{~kg}\right.$ of $\left.\mathrm{N} \mathrm{ha}^{-1}\right)$ & $605.00 \mathrm{a}$ & $3.12 \mathrm{a}$ & $25.38 \mathrm{a}$ & $67.08 \mathrm{a}$ \\
\hline $\mathrm{T} 4-\left(33.75 \mathrm{~kg}\right.$ of $\left.\mathrm{N} \mathrm{ha}^{-1}\right)$ & $425.00 \mathrm{~b}$ & $2.57 \mathrm{~b}$ & $20.67 \mathrm{c}$ & $47.18 \mathrm{~b}$ \\
\hline $\mathrm{T} 5-\left(45 \mathrm{~kg}\right.$ of $\left.\mathrm{N} \mathrm{ha}^{-1}\right)$ & $436.67 \mathrm{~b}$ & $2.32 \mathrm{~b}$ & $20.08 \mathrm{c}$ & $48.48 \mathrm{~b}$ \\
\hline $\mathrm{T} 6-\left(56.25 \mathrm{~kg}\right.$ of $\left.\mathrm{N} \mathrm{ha}^{-1}\right)$ & $327.67 \mathrm{~b}$ & $2.46 \mathrm{~b}$ & $22.38 \mathrm{~b}$ & $36.30 \mathrm{~b}$ \\
\hline $\mathrm{T} 7-\left(67.5 \mathrm{~kg}\right.$ of $\left.\mathrm{N} \mathrm{ha}^{-1}\right)$ & $572.00 \mathrm{a}$ & $3.28 \mathrm{a}$ & $20.33 \mathrm{c}$ & $63.48 \mathrm{a}$ \\
\hline $\mathrm{CV} \%$ & 24.04 & 14.67 & 9.79 & 24.03 \\
\hline
\end{tabular}

Averages followed by different letters in the lines differ significantly from each other by Scott-Knott test at $5 \%$ probability level.

The highest fresh shoot mass mean values were achieved by applying $11.25 \mathrm{~kg} \mathrm{~N} \mathrm{ha}^{-1}, 22.5$ $\mathrm{kg} \mathrm{N} \mathrm{ha}{ }^{-1}$ and $67.5 \mathrm{~kg}$. $\mathrm{N} \mathrm{ha}^{-1}$ doses that corresponded to T2, T3 and T7 treatments, respectively. These treatments did not differ from each other and were statistically superior to the other treatments assessed. T1, T4, T5 and T6 treatments, corresponding to the use of $0 \mathrm{~kg}$ $\mathrm{N} \mathrm{ha}^{-1}, 33.75 \mathrm{~kg} \mathrm{~N}^{-1}, 45 \mathrm{~kg} \mathrm{~N}^{-1}$ and $56.25 \mathrm{~kg} \mathrm{~N}^{-1}$, respectively, did not differ from each other.

The stem diameter of Vera lettuce was significantly influenced by nitrogen applications through fertigation, and the same tendency observed in the fresh shoot mass study was repeated, that is, the best performances were observed for T2, T3 and T7 treatments. These treatments also did not differ from each other, but were statistically superior to the other treatments (T1, T4, T5 and T6). In the same way as for the fresh shoot mass variable, T1, T4, T5 and T6 treatments did not differ from each other.

The Scott-Knott test revealed that T2 and T3 treatments produced plants with significantly higher root lengths than the other treatments applied. However, these treatments did not differ from each other. T6 treatment was statistically inferior to T2 and T3 treatments, and simultaneously was statistically superior to the other tested treatments (T1, T4, T5 and T7). TT4, T5 and T7, in turn, treatments did not differ from each other whereas managed to produce the same effect on the root length of curly lettuce plants. Moreover, they presented 
worse performance compared to treatments T2, T3 and T6 and at the same time were statistically superior to treatment $\mathrm{T} 1$. This last apparently provided insufficient nitrogen supply to lettuce plants and had the worst performance among treatments evaluated in the present work.

Furthermore, Vera variety plant productivity was significantly influenced by nitrogen fertigation, so that the best performances were achieved for T2, T3 and T7 treatments. However, the performance of these treatments did not differ from each other and at the same time were statistically superior to the performance of the other treatments applied in the scope of this study (T1, T4, T5 and T6) which also did not differ from each other.

As highlighted by Benini et al. (2005), Malavolta (2006) and Filgueira (2013) in their studies on lettuce crop, nitrogen is the second most extracted nutrient and its use in adequate doses may favor vegetative growth, mass accumulation and leaf area increase.

Santana et al. (2012) explained that stem diameter is an important characteristic for lettuce, as the consumer has a preference for larger heads when purchasing this product. Our results are consistent with those found by Porto et al. (1999) that observed better stem diameter values in lettuce following nitrogen fertilization.

According to Araújo et al. (2011), a more developed root system is desirable as it enables greater soil exploration and, consequently, greater water and nutrients absorption.

Bueno (1998) and Resende et al. (2012) also verified that nitrogen fertigation had a significantly positive effect on lettuce yield, though discrepancies in yield values can be explained by differences in the studied cultivars, fertigation frequency and edaphoclimatic conditions.

\section{Conclusion}

The use of nitrogen fertilization by fertigation provided, for the studied lettuce varieties and in most of the applied treatments, increase in the shoot fresh mass production (weight), stem diameter, root length and yield. Thus, it was observed that the nitrogen dosages employed via fertigation significantly influenced all growth and yield variables of Dora and Vera lettuce varieties.

\section{References}

Allen, R. G., Pereira, L. S., Raes, D., \& Smith, J. (2006). Evapotranspiration del cultivo: guias para la determinación de los requerimientos de agua de los cultivos. Roma: FAO, 298 p.

Almeida, T., Prado, R., Ribeiro Correia, M., Puga, A., \& Barbosa, J. (2011). Avaliação nutricional da alface cultivada em soluções nutritivas suprimidas de macronutrientes.. Biotemas, 24(2), 27-36. https://doi.org/10.5007/2175-7925.2011v24n2p27

Alves, P. F. S., Santos, S. R. dos., Kondo, M. K., Araújo, E. D., \& Oliveira, P. M. de. (2018). Fertirrigação do milho com água residuária sanitária tratada: crescimento e produção. Engenharia Sanitaria e Ambiental, 23(5), 833-839. https://doi.org/10.1590/s1413-41522018136152 
Araújo Neto, S. E., Ferreira, R. L. F., \& Pontes, F. S. T. (2009). Rentabilidade da produção da orgânica de cultivares de alface com diferentes preparos de solo e ambiente de cultivo. Ciência Rural, 39(5), 1362-1368. https://doi.org/10.1590/S0103-84782009005000071

Araújo, W. F., Souza, K. T. S., Viana, T. V. A., Azevedo, B. M., Barros, M. M., \& Marcolino, E. (2011). Lettuce response to nitrogen fertilization. Agro@mbiental Magazine Online, 5(1), 12-17. https://doi.org/10.18227/1982-8470ragro.v5i1.440

Benini, E. R. Y., Takahashi, H. W., \& Neves, C. S. V. (2005). Concentration and accumulation of macronutrients in lettuce grown in hydroponic and conventional systems. Semina: Agricultural Sciences, 26(3), 273-282. https://doi.org/10.5433/1679-0359.2005v26n3p273

Brzezinski, C. R., Abati, J., Geller, A., Werner, F., \& Zucareli, C. (2017). Produção de cultivares de alface americana sob dois sistemas de cultivo. Revista Ceres, 64(1), 83-89. https://doi.org/10.1590/0034-737x201764010012

Bueno, C. R. (1998). Nitrogen fertilization by drip fertigation for lettuce in protected environment. 54f. Dissertation (Master in Agronomy) - Federal University of Lavras, Lavras,

Carrijo, O. A., Souza, R. B. D., Marouelli, W. A., \& Andrade, R. J. D. Fertigation of vegetables. Brasilia: Embrapa Vegetables, 2004, 13 p. (Technical Circular, 32 - Embrapa Vegetables).

Diamante, M. S., Seabra J. S., Inagaki, A. M., Silva, M. B. da, \& Dallacort, R. (2013). Produção e resistência ao pendoamento de alfaces tipo lisa cultivadas sob diferentes ambientes. Revista Ciência Agronômica, 44(1), 133-140. https://doi.org/10.1590/S1806-66902013000100017

EMBRAPA, Brazilian Agricultural Research Corporation. (2018). Brazilian system of soil classification. Brasilia: Ministry of Agriculture, Livestock and Supply.

Filgueira, F. A. R. (2013). New olericulture manual ( $3^{\text {rd }}$ ed): Modern agrotechnology in the production and marketing of vegetables. Lush: UFV.

Goto, R., Guimarães, V. F., \& Echer, M. M. (2001). Aspectos fisiológicos e nutricionais no crescimento e desenvolvimento de plantas hortícolas. In: FOLEGATTI, M.V., CASARINI, E., BLANCO, F.F., BRASIL, R.P.C. do, RESENDE, R.S. (Coord.) Fertirrigação: flores, frutas e hortaliças. Guaíba: Agropecuária, 2, 241-268.

Instituto Agronômico De Campinas (IAC). Hortaliças: alface. Disponível em: http://www.iac.sp.gov.br/Tecnologias/Alface/Alface. Acesso em: 18/09/2019.

Kappes, C., Zancanaro, L., \& Jesus, F. V. D. (2013). Doses of nitrogen, via urea and ammonium nitrate, in cover in safrinha corn in succession to soybean. XII National Productivity Seminar. Golden, November 26-28.

Lopes, V. (2012). Roman lettuce grown under slow release nitrogen fertilization. Dissertation (Master in Agronomy) - Federal University of Lavras, Lavras-MG.

Malavolta, E. (2006). Plant Mineral Nutrition Handbook. Sao Paulo: Ceres. 506p. 
Marouelli, W. A. (2008). Irrigation in the production of vegetable seeds. Field and Business Magazine, Uberlândia, 2(34), 6-7.

Mota, J. H., da Silva, C. C. R., Yuri, J. E., \& de Resende, G. M. (2016). Produção de alface americana em função da adubação nitrogenada nas condições de primavera em Jataí-GO. Brazilian Journal of Agriculture, 91(2), 156-164.

Novais, R. F., Alvarez, V. H., Barros, N. F., Fontes, R. L. F., Cantarutti, R. B., \& Neves, J. C. (2007). Fertilidade do solo. Sociedade Brasileira de Ciência do Solo. Viçosa. 1017 pp.

Porto, V. C. N., Negreiros, M. Z., Bezerra Neto, F., \& Nogueira, I. C. C. (1999). Sources and doses of organic matter in lettuce production. Caatinga Magazine, Mossoró-RN, (12), 7-11.

Resende, G. M., Alvarenga, M. A. R., Yuri, J. E., \& Souza, R. J. (2012). Yield and macronutrient contents in lettuce as a function of nitrogen and molybdenum doses. Brazilian Horticulture, 30, 373-378. https://doi.org/10.1590/S0102-05362012000300003

Sala, F. C., \& Costa, C. P. (2012). Retrospectiva e tendência da alfacicultura brasileira. Horticultura Brasileira, 30(2), 187-194. https://doi.org/10.1590/S0102-05362012000200002

Santana, C. T. C. D., Santi, A., Dallacort, R., Santos, M. L., \& Menezes, C. B. D. (2012). Performance of lettuce cultivars in response to different doses of filter cake. Agricultural Science Magazine, 43(1), 22-29. https://doi.org/10.1590/S1806-66902012000100003

Silva, C. P. da, Garcia, K. G. V., Tosta, M. S. da, Cunha, C. S. M., \& Nascimento, C. D. V. do. (2014). Adubação nitrogenada no crescimento inicial de mudas de jaqueira. Enciclopédia Biosfera, 10(18), 174-180.

Sousa, T. P. D., Souza Neto, E. P., Silveira, L. R. D. S., Santos Filho, E. F. DOS, \& Maracajá, P. B. (2016). Lettuce production (Lactuca sativa L.), as a function of different concentrations and types of biofertilizers. Green Journal of Agroecology and Sustainable Development, 9(4), 168-172.

Taiz, L., Zeiger, E., Moller, I., \& Murphy, A. (2017). Fisiologia e desenvolvimento vegetal. 6.ed. Porto Alegre: Artmed, 888 p.

Takayanagui, O. M., Febrônio, L. H. P., Bergamini, A. M., Okino, M. H. T., Silva, A. A. M. C., Castro, E., ... Takayanagui, A. M. M. (2000). Fiscalização de hortas produtoras de verduras do município de Ribeirão Preto, SP. Revista da Sociedade Brasileira de Medicina Tropical, 33(2), 169-174. https://doi.org/10.1590/S0037-86822000000200002

Targino, A. J. O., Morais, N. H. M., Santos, J. M. A. P., Régis L. R. L., Milk, N. J. S., \& Souza, M. W. L. (2017). Fertigation strategy in lettuce crop under salt stress in protected environment. IV INOVAGRI, Fortaleza, 1-9.

Zamora, V. R. O, Silva, M. M da, Silva, G. F da, Santos J. J. A, Menezes, D., \& Menezes, S. M. de. (2019). Pulse drip irrigation and fertigation water depths in the water relations of coriander. Horticultura Brasileira, 37(1), 22-28.

https://doi.org/10.1590/s0102-053620190103 


\section{Macrothink}

Journal of Agricultural Studies

ISSN 2166-0379 2020, Vol. 8, No. 1

Zhang, H. J., Dong, H. Z., Li, W. J., \& Zhang, D. M. (2012). Effects of soil salinity and plant density on yield and leaf senescence of field-grown cotton, Journal of Agronomy and Crop Science, 198(1), 27-37. https://doi.org/10.1111/j.1439-037X.2011.00481.x

\section{Copyright Disclaimer}

Copyright for this article is retained by the author(s), with first publication rights granted to the journal.

This is an open-access article distributed under the terms and conditions of the Creative Commons Attribution license (http://creativecommons.org/licenses/by/4.0/). 